\title{
Abnormalities in bivalve larvae from the Puck Bay (Gulf of Gdansk, southern Baltic Sea) as an indicator of environmental pollution
}

Rafal Lasota ${ }^{1 *}$, Katarzyna Gierszewska1, Frédérique Viard²,3, Maciej Wolowicz ${ }^{1}$, Katarzyna Dobrzyn $^{1}$, Thierry Comtet ${ }^{2,3}$

${ }^{1}$ University of Gdansk, Faculty of Oceanography and Geography, Department of Marine Ecosystems Functioning, Laboratory of Estuarine Ecology, Al. M. Pilsudskiego 46, 81-372, Gdynia, Poland

${ }^{2}$ Sorbonne Universités, UPMC Univ Paris 06, UMR 7144, Equipe DIVCO, Station Biologique, Roscoff, France

${ }^{3}$ CNRS, UMR 7144, Adaptation et Diversité en Milieu Marin, Station Biologique, Roscoff, France

*corresponding author: ocerl@ug.edu.pl

Keywords: Mytilus trossulus, Cerastoderma glaucum, Mya arenaria, Limecola balthica, larval shell, deformities, veliger

Highlights: Abnormalities in shells and soft tissues were noted in bivalve larvae from Puck Bay. The ratio of abnormal larvae could be used as an indicator of environmental pollution. Postlarvae had deformations reminiscent of indentations on larval shell edges. The results suggested that the survival of larvae with shell abnormalities was low.

\section{ABSTRACT}

This study described the occurrence of abnormalities in bivalve larvae from the Puck Bay. Analyses of plankton samples collected in 2012-2013 showed that larval Mytilus trossulus, Mya arenaria, and Cerastoderma glaucum exhibited abnormalities that could indicate adverse environmental impacts. The deformities were mainly in shells, but missing soft tissue fragments and protruding vela were also noted. In addition to larval studies, we analyzed benthic postlarvae of Mytilus trossulus. Interestingly, grooves and notches at different locations of the prodissoconch, dissoconch, and shell margin were observed. Some of these deformations were reminiscent of the indentations found on the shell edge of larvae. Comparing the proportion of abnormal postlarvae to larvae with shell abnormalities suggested 
that the survival of larvae with shell abnormalities was low. Overall, our results suggested that the ratio of abnormal bivalve larvae could be used as an indicator of the biological effects of hazardous substances in the pelagic environment.

\section{INTRODUCTION}

Marine pollution affects coastal and estuarine ecosystems in many ways and at various scales, from the organism to community levels (Weis 2014). Because of their sensitivity to pollutants and their bio-accumulation ability, marine invertebrates, especially mollusks, have long been used to monitor the biological effects of contaminants and environmental quality (Rainbow and Phillips, 1993) by measuring diverse molecular, cellular and physiological biomarkers (e.g., Bolognesi et al. 1996; Wedderburn et al., 2000; Leinio and Lehtonen, 2005). Early life stages (embryos and larvae) of marine invertebrates are more sensitive to pollutants than adults of the same species (Connor, 1972; Calabrese et al., 1973; Pineda et al., 2012), and, thus, they offer the possibility of detecting lower levels of pollution. Exposed embryos and larvae typically show retarded development, increased morphological abnormalities, and higher mortality (e.g., Calabrese et al., 1977; Klöckner et al., 1985; Fichet and Miramand, 1998; Beiras and Bellas, 2008; Mai et al. 2012; Stefansson et al. 2016). In the particular case of bivalves, slow growth, increased percentages of abnormal D-shaped veliger larvae, tissue necrosis resulting from damage to the shell gland, and abnormal velar structures are some of the documented effects of harmful compounds (Calabrese et al., 1977; His et al, 1999; Inoue et al. 2006). Such developmental alterations have been used to develop embryo-larval bio-assays, especially using oysters (Crassostrea spp.) and mussels (Mytilus spp.), to examine the effects of a variety of contaminants such as heavy metals, pesticides, detergents, and, ultimately, to assess contamination levels of waters and sediments (e.g., His et al., 1999; Wedderburn et al, 2000, Quiniou et al., 2007).

Bio-assays are typically carried out through embryo exposure to contaminants or to waters (or sediments) over a short period (24-48h), with mortality and level of developmental abnormalities as the endpoints. Although abnormality rates in embryos and larvae are important in bio-assays and are recommended as one of the standard response variables to be measured routinely in assessments of multistressor effects (Przeslawski et al. 2015), they are targeted infrequently in field studies (but see Lehtonen et al., 2014 and references therein), especially in those of mollusks. One explanation for the scarcity of such approaches could be the difficulty of identifying larvae at the species level, especially in groups like bivalves. Not only are early larval stages very difficult to distinguish based only on morphology (Garland and Zimmer, 2002; Hendriks et al., 2005), morphological abnormalities caused by pollution can make identification even more difficult. Advances in molecular-based methods of identifying 
species, i.e., DNA barcoding using standard sequencing or PCR-based techniques, permits identifying species at the larval stage (Larsen et al. 2005, Le Goff Vitry et al., 2007a;b, Comtet et al. 2015). Thus, they offer new opportunities to examine larval abnormalities and to use early developmental stages in field studies.

During a routine analysis of meroplankton in the Gulf of Gdansk, we discovered particularly high numbers of abnormal bivalve larvae, which prompted us to assess carefully their relative abundance in a time-series sampling. In the present study, we report the occurrence of these abnormalities in larvae of four species of bivalves that were identified accurately with molecular tools. We also report abnormalities in benthic postlarvae of Mytilus trossulus. Based on our findings, we discuss the use of larval abnormality rates as field bio-indicators of pollution effects.

\section{MATERIALS AND METHODS}

\section{Study area}

The Puck Bay is located in the western part of the Gulf of Gdansk and is separated from the open sea by the Hel Peninsula (Fig. 1). The bay is divided by a shallow sand bar into the inner Puck Bay (known as the Puck Lagoon) and the outer Puck Bay. It is under the influence of marine waters from the deep regions of the Gulf of Gdansk and terrestrial waters, including from the Vistula, which is the longest and largest river in Poland. Water temperature in the outer Puck Bay varies between 1 to $21^{\circ} \mathrm{C}$, while the salinity reaches an average value of 7.65 (see Kruk-Dowgiałło and Szaniawska, 2008 for references). Their geographical locations and specific hydrological conditions mean the Gulf of Gdansk and the Puck Bay face significant ecological threats. Low salinity, limited water exchange, highly developed agriculture and processing, urbanized coastal zone, and river and sewage treatment plant water inflow mean that the organisms living in this area are particularly vulnerable to increasing loads of nutrients and toxic substances such as metals, organochlorine compounds, polycyclic aromatic hydrocarbons, endocrine disrupting compounds, and antibiotics (HELCOM, 2010).

\section{Sampling}

Bivalve larvae were collected from the r/v Oceanograf 2 in 2012-2013 using a WP2 plankton

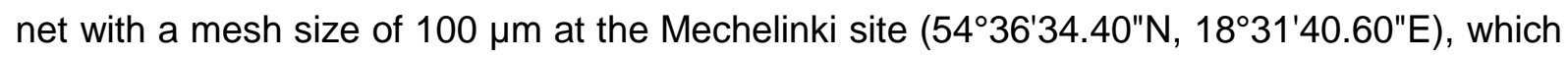
is located near the mouth of the sewage outlet of the treatment plant in the village of Debogorze (Fig. 1). On each sampling date, one plankton sample was collected vertically from the bottom (depth 7-8m) to the surface. After collection, the plankton was preserved with $96 \%$ ethanol and stored in a refrigerator until sorting. High density samples were sorted in a Motoda 
plankton box splitter. When available, more than one hundred bivalve larvae were then sorted randomly for further identification and examination. If the sample contained fewer individuals, all of them were analyzed. Sampling dates and the number of larvae analyzed are presented in Table 1.

Table 1. Sampling dates and numbers $(\mathrm{N})$ of analyzed larvae

\begin{tabular}{|l|l|l|l|l|l|l|l|l|l|l|l|l|}
\hline date & 8.7 .12 & 18.7 .12 & 25.7 .12 & 18.9 .12 & 24.10 .12 & 7.12 .12 & 26.2 .13 & 9.6 .13 & 24.7 .13 & 30.8 .13 & 30.9 .13 & 14.10 .13 \\
\hline $\mathbf{N}$ & 134 & 127 & 130 & 72 & 43 & 5 & 2 & 114 & 128 & 14 & 13 & 66 \\
\hline
\end{tabular}

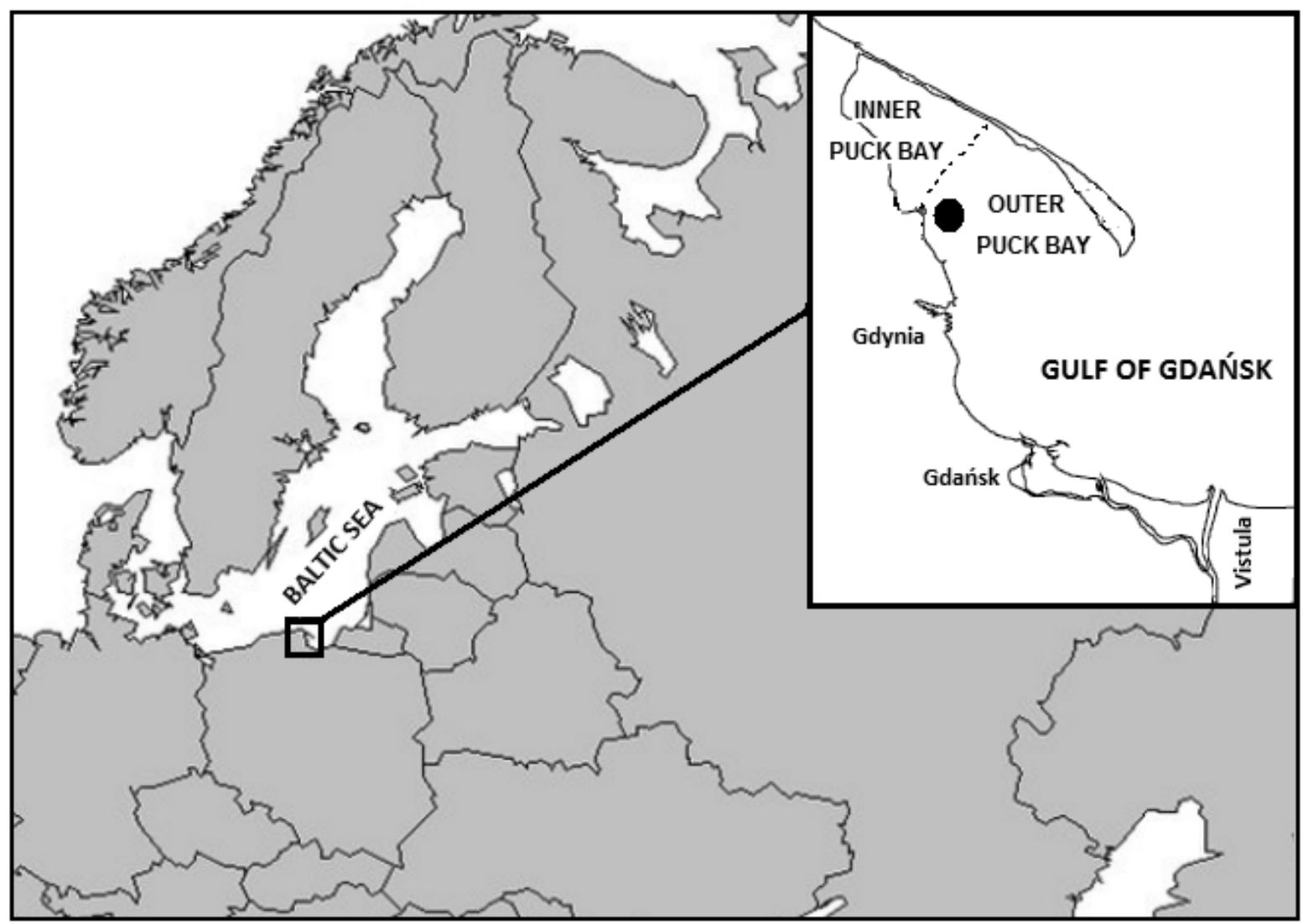

Fig. 1. Location of the sampling site (black dot)

A sediment sample was collected at the same site on 23/08/2012 with a Van Veen grab from onboard the r/v Oceanograf 2. Bivalves (mostly Mytilus trossulus) were sorted roughly and 
immediately preserved and stored in $96 \%$ ethanol. Later, the sample was examined to search for bivalve postlarvae. More than 100 postlarvae were sorted and easily identified as $M$. trossulus based on their morphology (e.g., Fuller and Lutz, 1989; Bownes et al., 2008; Lasota et al., 2013).

\section{Identification of the larvae}

Four bivalve species dominate in the Puck Bay: Mytilus trossulus, Limecola balthica, Mya arenaria, and Cerastoderma glaucum (e.g., Węsławski et al., 2013). Recent observations reported the occurrence of the non-native Conrad's false mussel Mytilopsis leucophaeata close to the sampling area (Dziubińska 2011, Brzana \& Janas 2016) and in the Vistula Delta located in the eastern part of the Gulf of Gdansk (Brzana et al. 2017), and the non-native clam Rangia cuneata in the Vistula Delta and Vistula Lagoon further east (Janas et al. 2014, Warzocha et al. 2016). Regarding the density and local occurrence of these two non-native species, we considered their potential contribution to the meroplankton of our study area negligible. This assumption is supported by the lack of any recruitment event on artificial substrates in this area during 7 years of observations (Brzana \& Janas, 2016; Sokołowski et al., 2017).

Larvae at the veliger and pediveliger stages were thus sorted based on morphological characteristics into two groups: 1) Mytilus trossulus and 2) other species. Mytilus trossulus larvae are indeed easy to identify at this stage (Aucoin et al., 2004; Lasota et al., 2013). Species identification of larvae belonging to group 2, as well as larvae at the D-shaped stage (which can include M. trossulus larvae), was done using a molecular approach. Larval genetic material was isolated based on a procedure described in Lasota et al. (2013), and species were identified with single-step nested multiplex PCR developed by Larsen et al. (2005), which targets a fragment of the 18S rRNA gene. Amplicons were separated electrophoretically on 2 $\%$ agarose gel and visualized using GelRedTM. The pattern of electrophoregrams obtained for larvae were compared to those obtained for adults.

This technique involved the simultaneous use of a pair of universal primers and internal primers specific to each from four native species occurring in the Puck Bay. Since the primers were developed originally by Larsen et al. (2005) to identify Mya spp., L. balthica, C. edule, and $M$. edulis, among others, the authors mention that they cannot exclude that their primers would work on other species from these genera (Larsen et al., 2007). Thus, we first checked the usefulness of these primers to distinguish adults of our four target species, in particular $M$. trossulus and C. glaucum, with which the method has never been applied. It turned out that the primers worked perfectly to discriminate these species, as is shown in Figure 2. In order to exclude possible molecular misidentification of non-native bivalves Mytilopsis leucophaeata and Rangia cuneata with targeted species, we also checked whether the specific primers 
would amplify non-native species. None of the target-specific primers amplify DNA in Rangia cuneata. Concerning Mytilopsis leucophaeata, because we failed to get DNA for this species, we used DNA from Dreissena polymorpha as a substitute. We chose this species because it belongs to the same family as $M$. leucophaeata (Dreissenidae), and the same order Myida as Mya arenaria (target species), for which the Mya1754R primer was designed (Larsen et al. 2005). In addition, D. polymorpha and M. leucophaeata share the same 3 mismatches with this Myida-specific primer, making them likely to show the same electrophoresis pattern. None of the target-specific primers amplify any specific band in $D$. polymorpha. These results thus confirm the reliability of our molecular identification of larvae. In total, 412 larvae were identified using this molecular method.

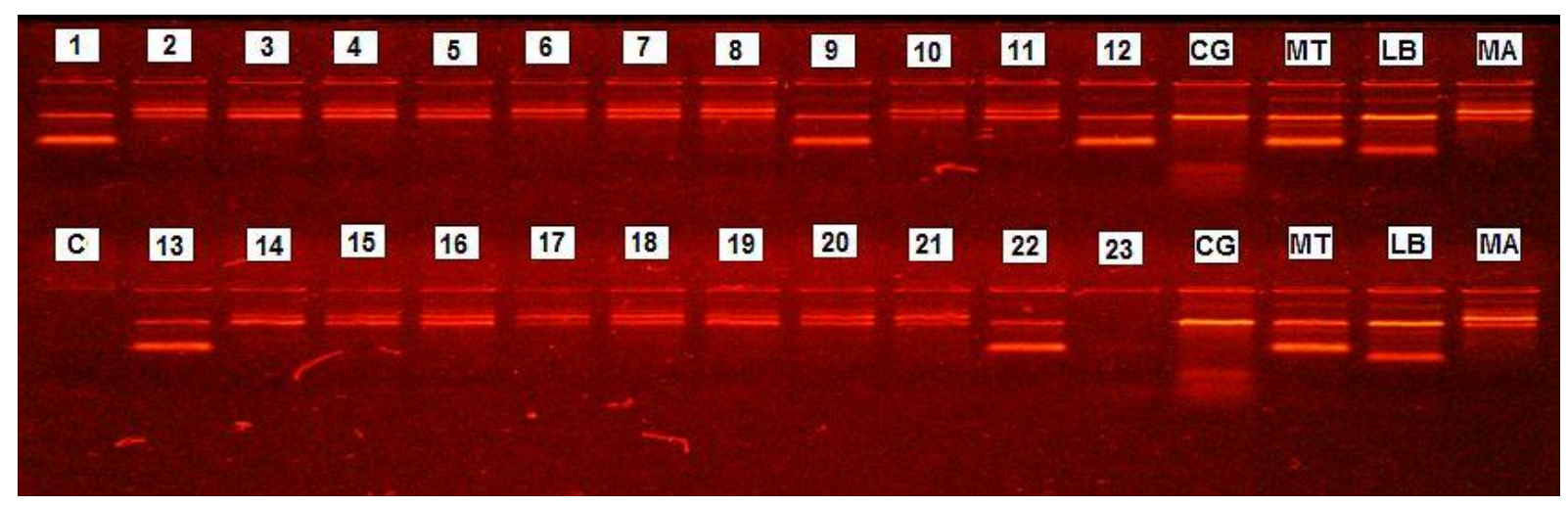

Fig. 2. Example of an electrophoregram. Reference individuals: MA - Mya arenaria, LB - Limecola balthica, MT - Mytilus trossulus, CG - Cerastoderma glaucum; C - PCR negative control; 1-23 - tested larvae.

\section{Classification of abnormalities}

Before molecular identification, which destroys the specimens, the larvae were examined carefully to detect morphological abnormalities that are commonly observed in larvae exposed to various contaminants (e.g., His et al., 1999; Wedderburn et al., 2000). Abnormal larvae were classified according to three categories of abnormalities: 1 ) shell deformations (changes in the outer margin, including various types of visible indentations); 2) losses of soft tissue (patches of missing tissue); 3) protruding velum (Fig. 3). 


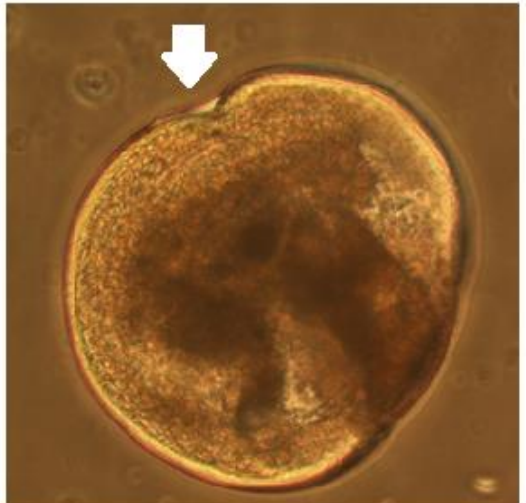

a)

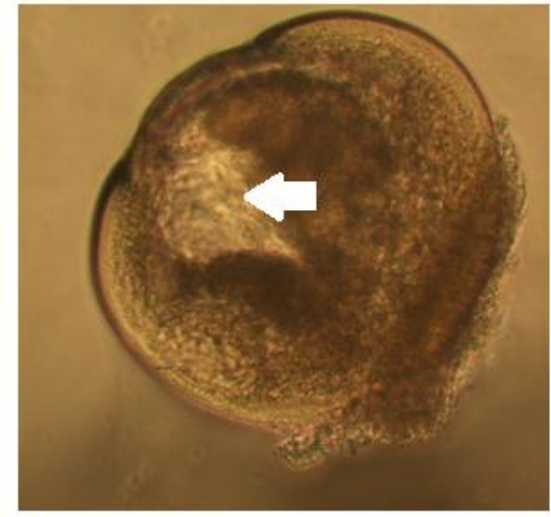

b)

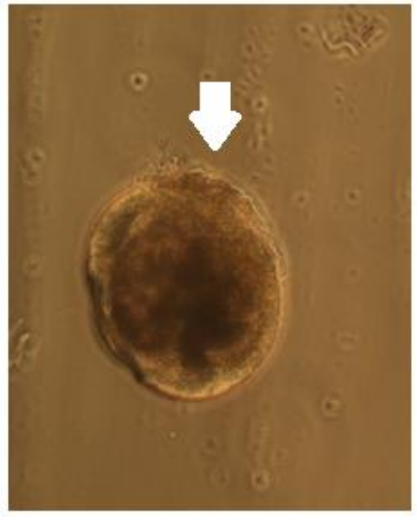

c)

Fig. 3. M. trossulus larvae with shell deformation (a), loss of tissue (b), protruding velum (c)

\section{Observations of postlarvae}

All $M$. trossolus postlarvae were carefully examined with a dissecting microscope under both unpolarized and polarized light to search for shell abnormalities by focusing on the dissoconch and the prodissoconch II / dissoconch boundary. Specimens exhibiting potential abnormalities and a few normal specimens were then prepared for scanning electron microscopy (SEM). Preserved specimens were immersed in a $5.2 \%$ sodium hypochlorite solution to dissolve soft tissues and separate the two valves (Comtet et al. 2000). Disarticulated valves were then rinsed with distilled water, air-dried, mounted on SEM pin stubs with adhesive tabs and coated with gold. The samples were examined under a Phenom G2 Pro desktop SEM. 


\section{RESULTS}

\section{Species composition of bivalve larvae}

Based on both morphological and molecular identification, the bivalve larvae present in samples belonged to four species reported in the Puck Bay. Mytilus trossulus and/or Mya arenaria clearly dominated throughout the year (Fig. 4). They represented from 59 to $100 \%$ of all larvae in the 12 samples at an average of $92 \%$ across all samples.

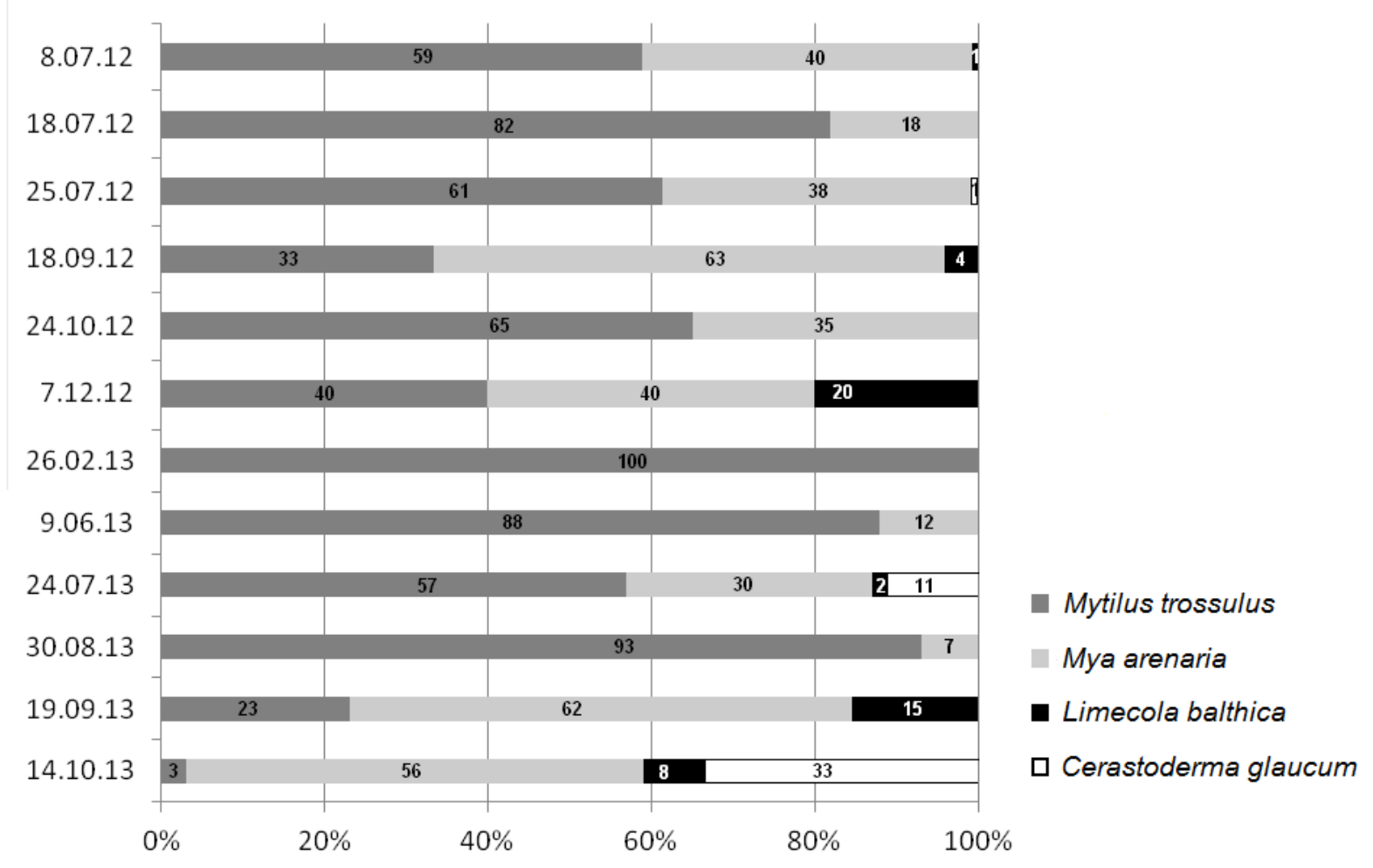

Fig. 4. Relative species composition of the bivalve larval pool sampled in Puck Bay (percentage)

\section{Temporal changes in proportions and types of larval abnormalities}

The proportion of abnormal larvae differed among months (Fig. 5). In 2012, the largest proportion of abnormal larvae observed in a sample (25.07.12) was $34 \%$, while the smallest percentage of individuals exhibiting abnormalities, $1 \%$, was recorded in sample collected on 08.07.12. In 2013, the highest percentage of abnormal larvae was $36 \%$ (30.08.13), while in one sample (26.02.13) no abnormal larvae were found. 


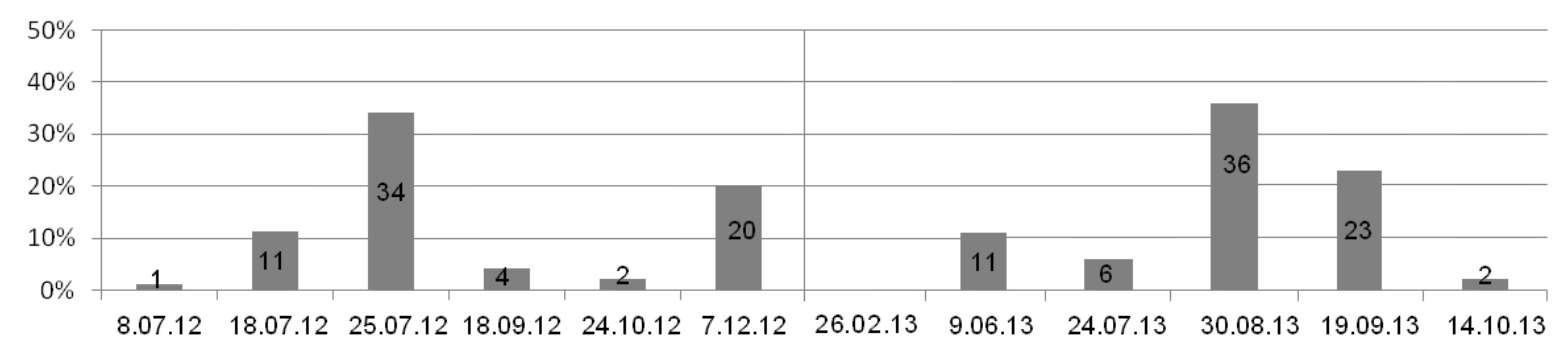

Fig. 5. Temporal variations in abnormality rates (percent of abnormal larvae) of bivalve larvae sampled in the Puck Bay in 2012-2013. All species.

Among the four species studied, $M$. trossulus and $M$. arenaria larvae were the most affected by abnormalities (Fig. 6), with percentages of abnormal larvae as high as $67 \%$ and $50 \%$, respectively. In July 2013, 7 \% of C. glaucum larvae had abnormalities (Fig. 6), but no abnormalities were noted in L. balthica.

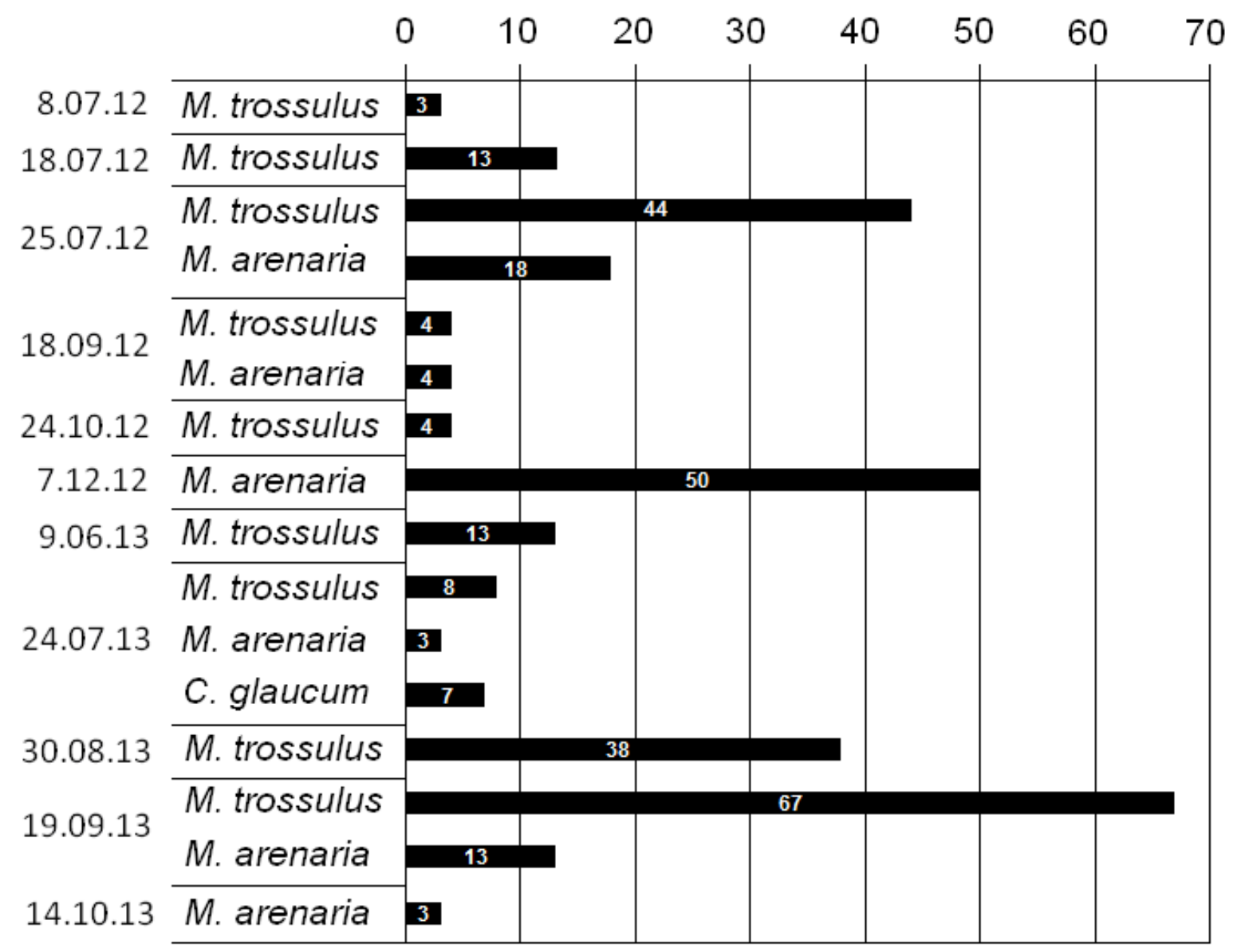


Fig. 6. Percentage of abnormal larvae of each species. Only species with abnormal larvae are shown in particular samples.

All three types of abnormalities were observed (Fig. 7a) in M. trossulus, but most of them were shell deformations and loss of soft tissues. These two types of abnormalities were also observed in M. arenaria (Fig 7b). Only shell deformations were observed in C. glaucum. Overall, shell deformations were the most commonly observed abnormalities although the relative contribution of each type of abnormality differed among months (Fig. 7).
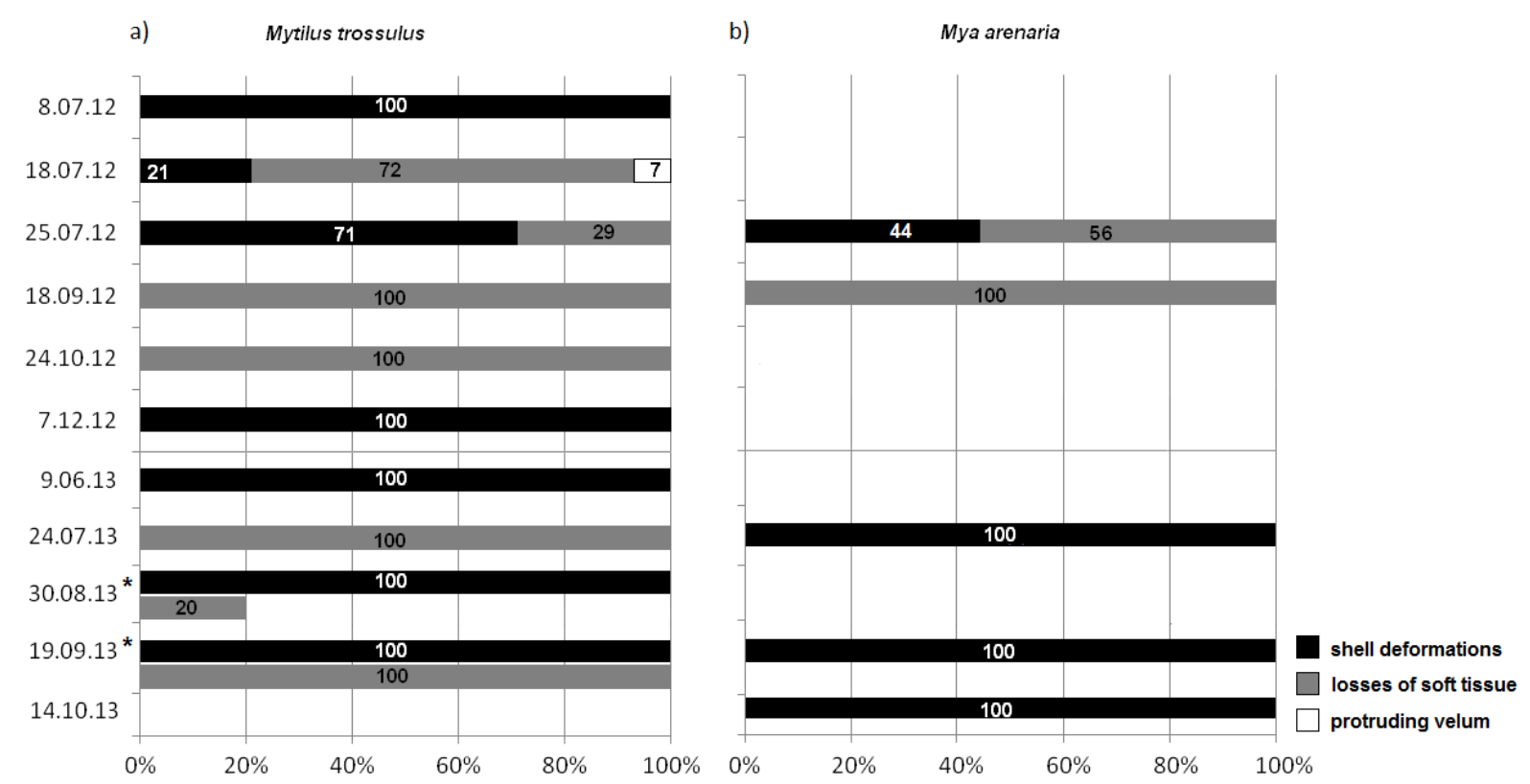

Fig. 7. Distribution (percentage) of different abnormalities in Mytilus trossulus (a) and Mya arenaria (b) larvae. Asterisks indicate samples with larvae exhibiting two types of abnormalities simultaneously.

\section{Abnormalities in postlarvae}

Several types of shell abnormalities were observed in benthic Mytilus trossulus postlarvae (Fig. 8). A few individuals exhibited grooves at different locations on the dissoconch, either at the shell margin (Fig. 8 b) or at the prodissoconch II (PII)/dissoconch (D) boundary (Fig. 8 b, c, d). In one case, one groove was in line with a potential abnormality of the PII/D boundary (Fig. 8 d). Two postlarvae exhibited abnormal PII/D boundaries, one with two slight undulations at the PII margin (Fig. $8 \mathrm{~d}$ ) and the other with a severe notch at the PII margin (Fig. 8 e, f). A severe deformation was observed in one individual that exhibited a rolled-up shell margin (Fig. $8 \mathrm{~g}$ ). 
Erosion scars on the outer surface of the PIl were also observed on one individual (Fig. $8 \mathrm{~h}$ ). Overall, less than $10 \%$ of the postlarvae examined exhibited at least one type of abnormality.
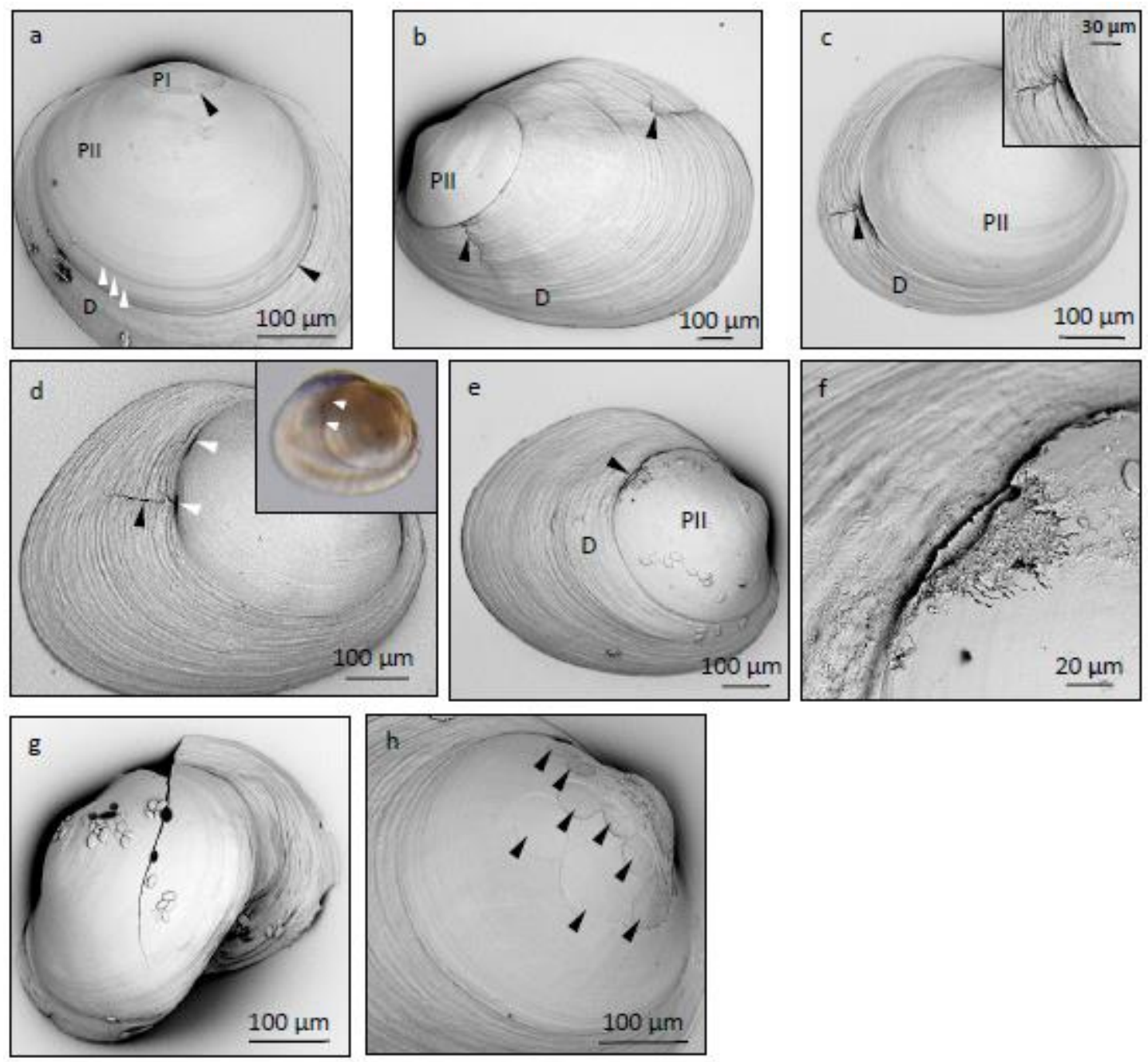

Fig. 8. Mytilus trossulus. Abnormalities observed in benthic postlarvae collected in the Puck Bay, Gulf of Gdansk (Baltic Sea). a - normal postlarva, showing the larval shell prodissoconch I (PI) and prodissoconch II (PII), postlarval shell dissoconch (D), and their boundaries (black arrowheads) with visible growth lines (white arrowheads); $b$ - left valve of a $1000-\mu m$ postlarva showing abnormal grooves on the dissoconch (arrowheads); c - right valve of a $480-\mu \mathrm{m}$ postlarva, showing a groove (arrowhead) close to the PII/D boundary, insert - detail; $d$ - right valve of a $600-\mu \mathrm{m}$ postlarva showing two types of abnormalities, a groove on the dissoconch (black arrowhead) and two potential indentations of the PII/D boundary (white arrowheads), insert - same individual before sample preparation under transmitted light showing the two visible indentations; e - right valve of a $680-\mu \mathrm{m}$ postlarva, showing a notch on the PII/D boundary (arrowhead), the left valve had a similar but less severe deformation (not shown); $f$ - detail of e; $g$ - left valve of a postlarva showing the rolled-up ventral margin; $\mathrm{h}$ - prodissoconch II of a $600-\mu \mathrm{m}$ postlarva showing erosion marks (arrowheads). 


\section{DISCUSSION}

\section{Are larval abnormalities symptoms of environmental pollution?}

The data from the present study showed that a substantial proportion of bivalve larvae from the Puck Bay, up to $36 \%$ in some samples, exhibited several types of abnormalities, including shell deformities and soft tissues abnormalities (e.g., a protruding velum). Among the four species occurring in this part of the Baltic Sea, three were affected-Mytilus trossulus, Mya arenaria and Cerastoderma glaucum. In contrast, Limecola balthica was found to be free from any abnormalities, but only 14 larvae were examined. On several occasions, the percentage of abnormalities in the two most abundant species ( $M$. trossulus and $M$. arenaria) reached high values of up to $67 \%$. These values are much higher than those observed in laboratory-reared larvae under "normal" conditions and those commonly noted in bioassays, which are typically less than 10-20\%. Interestingly, they do agree with values reported after acute exposure experiments (His et al., 1997; His et al., 1999). It should be noted, however, that the highest values in this study were observed in the fall/winter samples of small numbers of individuals; thus, they could be increased artificially by sampling drift. Nevertheless, in the sample from July 25, 2012 (130 larvae, including 79 M. trossulus), approximately $44 \%$ of $M$. trossulus larvae were abnormal, and this is likely explained by the adverse impact of environmental conditions. The abnormalities observed in this study are typically observed when bivalve embryos or larvae are exposed to a wide range of pollutants (e.g., Money et al., 2011; Mai et al., 2012; Vignier et al., 2015; Finch et al., 2016; and references therein). Although these abnormalities are not specific to any particular chemical, they could result from both adult and larval exposure to contaminants. As previously mentioned, the Gulf of Gdansk is particularly vulnerable to contamination from many toxic substances from different sources (e.g., Korpinen et al., 2012, 2013). According to HELCOM's 2010 integrated classification of "hazardous substances status," $60 \%$ of the assessment units in the Gulf of Gdansk were of a "moderate" status, $20 \%$ - "poor," and only 20\% - "good." Further, among the 137 assessment units in the different sub-basins of the Baltic Sea, the highest contamination ratios (i.e., the highest concentrations in relation to target levels) of four substances, namely benz[a]anthracene (a polycyclic aromatic hydrocarbon), cesium-137, mercury, and PCBs (HELCOM, 2010), were observed in the Gulf of Gdansk. Additionally, the sampling site used in the present study is very close to a sewage treatment plant outlet, which is one of the greatest sources of endocrine-disrupting compounds, namely bisphenol A , 4-tert-octylphenol, and 4-nonyl-phenol in the Gulf of Gdansk (Staniszewska et al., 2014). 
To our knowledge, the present study is one of a few, if not the first, to report such high rates of abnormalities in pelagic bivalve larvae, and previous surveys conducted in the Gulf of Gdansk, where bivalve larvae dominate meroplankton communities, failed to detect abnormal larvae (Józefczuk et al., 2003 ; Mudrak and Żmijewska, 2007). Similar results with high rates of morphological malformations in field samples were reported in fish embryos collected in heavily polluted areas in the southeastern North Sea (Cameron et al. 1992) and in the western Baltic Sea (von Westernhagen et al., 1988).

If pollutants likely explained our observations because of the high level of contamination in the study area, other factors could also have been involved. In particular, low salinities have been shown to increase the rate of abnormalities in larval M. galloprovincialis (Hrs-Brenko et al., 1977) and to alter the potential effects of pollutants in various ways depending on the species (Deruytter et al., 2015; Gamain et al. 2016). Thus, we cannot exclude that the low salinities prevailing in the Puck Bay explain some of the abnormalities either alone or in combination with pollutants, although local adaptation cannot be excluded (Stickney, 1964; Newkirk, 1978). Similar abnormalities can also arise from low-pH exposures (e.g., Kurihara et al., 2008; Parker et al., 2010; Andersen et al., 2013; Barros et al., 2013; Waldbusser et al., 2015) and less obvious factors like sound (Aguilar de Soto et al., 2013; Carroll et al., 2017) and pathogens (e.g., herpes virus causing velar lesions; Renault and Novoa, 2004). Temporal variation in the rates of abnormalities within particular species was noted. This could also indicate a synergistic effect of abiotic factors that vary seasonally and pollutants. Many studies have also shown that temperature and salinity can modify strongly the toxicity of pollutants. Vulnerability to pollutants can also vary with the physiological state of an organism. Understanding possible interactions among contamination and other abiotic and biotic factors and how they determine the level of abnormalities in larvae requires further detailed research.

\section{From larvae to postlarvae}

The potential consequences for recruitment success of the occurrence of the abnormalities observed in pelagic larvae is unknown. To date, most laboratory studies have comprised short term experiments (typically 24-48 h) and did not assess the later survival of abnormal larvae, although some studies have concluded that most abnormal larvae will never metamorphose in nature (Hrs-Brenko et al., 1977, Liu et al. 2009). Our observations of two (i.e., less than $2 \%$ ) postlarvae of Mytilus trossulus that exhibited damage (undulation or notches) at the margin of the prodissoconch II (larval shell) are reminiscent of indentations seen on the shell edge of pelagic larvae. This result suggested that abnormal larvae could settle and survive, at least for some time. However, a rough comparison of the proportion of postlarvae with abnormalities (approximately $2 \%$ ) and the proportion of pelagic larvae with shell abnormalities one month 
before sampling the postlarvae (July 25, 2012; approximately $44 \%$ ) suggests that the survival of larvae with shell abnormalities is low. Similar interpretations were reported in fish embryos by von Westernhagen et al. (1988), who observed higher rates of abnormalities in earlier stages, which was a result they explained by higher mortality rates in abnormal embryos.

Other abnormalities observed on benthic postlarvae of Mytilus trossulus were located on the dissoconch, which suggested they were produced post-settlement. The grooves closely resembled those described by Sunila and Lindström (1985) on adult Mytilus edulis experimentally exposed to copper and cadmium in brackish waters (salinity of 7) and those reported in adult Perna viridis from polluted sites off of the Malaysian coast (Yap et al. 2002). Similarly, the round scars observed at the surface of the prodissoconch II of a $600-\mu \mathrm{m}$ individual can appear to be like some of the shell deformities (craters and crevices) reported by Smolarz and Bradtke (2011) on adult Limecola balthica from the Baltic Sea, which they attributed to pollution and other environmental factors. Other types of shell deformities (flexure at the ventral margin, elongation of the posterior end) were observed in adult $L$. balthica from the Gulf of Gdansk that also had high concentrations of trace metals such as As, $\mathrm{Ag}, \mathrm{Cd}, \mathrm{Pb}$, $\mathrm{Cu}$ and $\mathrm{Zn}$ in their soft tissues (Sokołowski et al., 2002) and cytogenetic alterations (Sokolowski et al., 2004). Interestingly, in the present study, we did not observe larval abnormalities in L. balthica. This would support the hypothesis of Sokolowski et al. (2008) that deformities in adult clams could be interpreted as acclimatization mechanisms to the low oxygen and high hydrogen sulfide concentrations prevailing in the deep areas of the Gulf of Gdansk, or at least those that occur only during the postlarval stage. However, this should be confirmed by examining greater numbers of larvae of this species. In contrast to the studies mentioned above, which focused on adult bivalves, in the present work, the proportion of postlarvae with abnormalities was very low (less than $10 \%$ ). It is noteworthy that adult mussels at this site also exhibited abnormal grooves (authors' personal observations). Whether these types of abnormalities are linked to pollution alone cannot be confirmed based on our dataset. However, with regard to pelagic larvae, the similarity between our observations and previously reported deformities in polluted areas support this hypothesis. In this context, it is noteworthy that the most severe shell abnormality we observed was the rolled-up shell margin (Fig. $8 \mathrm{~g}$ ) that was similar to that pictured in Lehnberg and Theede (1979) in Mytilus edulis larvae exposed to high cadmium concentrations.

\section{Larval abnormalities in the field as a bioindicator of environment quality}

Assessing ecosystem health not only requires measuring contaminant concentrations in water, sediments, and organisms, but also assessing their biological effects in laboratory bioassays and field studies (Lehtonen et al. 2014). This is why developmental alterations are proposed as non-specific biomarkers for assessing the effects contaminants have on the reproductive 
outputs of target species based on field observations. In benthic ecosystems, developmental aberrations in brooded embryos of the gastropod Littorina saxatilis (Dixon and Pollard, 1985) or the amphipod Monoporeia affinis (Sundelin and Eriksson, 1998) were proposed as indicators of pollution effects, and the latter species is now considered a core indicator in Baltic Sea monitoring programs (Lehtonen et al., 2014; Reutgard et al., 2014; Löf et al., 2016). Substantial work has already been conducted on developmental abnormalities in fish embryos and larvae, which have also been suggested as biomarkers (von Westernhagen et al., 1988; Cameron et al., 1992; Cameron et al., 1996).

Our observations suggest that the percentage of abnormalities in the bivalve larvae collected in the field could be used as a candidate indicator for assessing the biological effects of hazardous substances on plankton. One advantage of using abnormal larvae collected in the field as a biomarker is that it integrates the direct effects contaminants have on larvae and parental exposure, which can produce larval abnormalities by itself (Vaschenko et al., 1997; Baussant et al., 2011). Further, targeting local populations permits comparing the responses of distinct populations and environments. At similar levels of contaminants, this comparison could be helpful to identify populations in which abnormalities are reduced, which could suggest that acclimatization or local adaptation have occurred. Examining populations in the field is also a pre-requisite to understanding to what extent biomarkers vary across sampling locations. This also establishes its robustness. As suggested by Pain-Devin et al. (2014) in their study of zebra mussels, population investigations are needed to describe better the link between biomarker baselines and population health.

For the first time in this paper, we report high rates of abnormalities in pelagic bivalve larvae, which suggest that environmental conditions, particularly pollutants, have negative impacts. In the Gulf of Gdansk, bivalve larvae dominate the meroplankton particularly from April to September (Józefczuk et al., 2003 ; Mudrak and Żmijewska, 2007), and they are a reliable target for monitoring purposes and the development of biomarkers. Other groups, however, could also be targeted such as sea urchins (e.g., Naidenko et al. 1997) provided that the composition of the meroplankton of the study area is known. These results were obtained thanks to the application of DNA-based tools, which permit accurately identifying species at the larval stage. This is necessary because the bivalve species examined in the present study are very similar in the early developmental stages, and because morphological abnormalities can challenge species identification. The DNA-based approach for individual larva is not cost effective. In further studies, we propose using one of two alternatives: 1) High-ThroughputSequencing methods that would be obtained from entire batches of abnormal larvae that would permit determining simultaneously species composition and the percentage of larval abnormalities, as in the present study; or 2) targeting only $M$. trossulus larvae, because they 
are easier to distinguish morphologically and were shown in the present work to be the most affected by abnormalities. Finally, we advocate for further investigations at additional sites to investigate possible variations in population responses to local environmental conditions.

\section{ACKNOWLEDGMENTS}

This study was made possible by National Science Centre, Poland (project no. N N304 785340) and was supported by French-Polish scientific cooperation program Polonium.

Sophie Le Panse (Merlmage microscopy platform, Station Biologique de Roscoff) and lan Probert (FR2424, Station Biologique de Roscoff) are thanked for access and help in scanning electron microscopy.

\section{REFERENCES}

Aguilar de Soto N, Delorme N, Atkins J, Howard S, Williams J, Johnson M., 2013, Anthropogenic noise causes body malformations and delays development in marine larvae. Sci Rep 3: 2831

Andersen S, Grefsrud ES, Harboe T., 2013, Effect of increased pCO2 level on early shell development in great scallop (Pecten maximus Lamarck) larvae. Biogeosciences 10: 61616184

Aucoin F, Doiron S, Nadeau M., 2004, Guide to sampling and identifying larvae of species of maricultural interest, Guide publication G005, New Brunswick, Canada, 73p.

Barros P, Sobral P, Range P, Chícharo L, Matias D., 2013, Effects of sea-water acidification on fertilization and larval development of the oyster Crassostrea gigas. J Exp Mar Biol Ecol 440: $200-206$

Baussant T, Ortiz-Zarragoitia M, Cajaraville M.P, Bechmann R.K, Taban I.C, Sanni S., 2011, Effects of chronic exposure to dispersed oil on selected reproductive processes in adult blue mussels (Mytilus edulis) and the consequences for the early life stages of their larvae. Mar Pollut Bull 62: 1437-1445

Beiras R, Bellas J., 2008, Inhibition of embryo development of the Mytilus galloprovincialis marine mussel by organic pollutants; assessment of risk for its extensive culture in the Galician Rias. Aquaculture 277: 208-212

Bolognesi C, Rabboni R, Roggieri P., 1996, Genotoxicity biomarkers in M. galloprovincialis as indicators of marine pollutants. Comp Biochem Physiol Part C 113: 319-323 
Bownes S, Barker NP, McQuaid CD., 2008, Morphological identification of primary settlers and post-larvae of three mussel species from the coast of South Africa. Afr J Mar Sci 30:233-240

Brzana R, Janas U, 2016, Artificial hard substrate as a habitat for hard bottom benthic assemblages in the southern part of the Baltic Sea - a preliminary study. Oceanol Hydrobiol Stud 45:121-130

Brzana R, Janas U, Borecka A, 2017, New records of Conrad's false mussel Mytilopsis leucophaeata (Conrad, 1831) in the Vistula Delta. Oceanol Hydrobiol Stud 46:231-236

Calabrese A, Collier RS, Nelson DA, Maclnnes JR., 1973, The toxicity of heavy metals to embryos of the American oyster Crassostrea virginica. Mar Biol 18:162-166Calabrese A, Maclnnes JR, Nelson DA, Miller JE., 1977, Survival and growth of bivalve larvae under heavymetal stress. Mar Biol 41:179-184

Cameron P, Berg J, Dethlefsen V, von Westernhagen H., 1992, Developmental defects in pelagic embryos of several flatfish species in the Southern North Sea. Neth $\mathrm{J}$ Sea Res 29:239-256

Cameron P, Berg J, Von Westernhagen H., 1996, Biological effects monitoring of the North Sea employing fish embryological data. Environ Monit Assess 40:107-124

Carroll AG, Przeslawski R, Duncan A, Gunning M, Bruce B., 2017, A critical review of the potential impacts of marine seismic surveys on fish and invertebrates. Mar Pollut Bull 114: 924

Comtet T, Jollivet D, Khripounoff A, Segonzac M, Dixon DR., 2000, Molecular and morphological identification of settlement-stage vent mussel larvae, Bathymodiolus azoricus (Bivalvia: Mytilidae), preserved in situ at active vent fields on the Mid-Atlantic Ridge. Limnol Oceanogr 45: 1655-1661

Comtet T, Sandionigi A, Viard F, Casiraghi M., 2015, DNA (meta)barcoding of biological invasions: a powerful tool to elucidate invasion processes and help managing aliens. Biol Invas 17: 905-922

Connor PM., 1972, Acute toxicity of heavy metals to some marine larvae. Mar Pollut Bull 3: 190-192

Deruytter D, Vandegehuchte MB, Garrevoet J, De Laender F, Vergucht E, Delbeke K, Blust R, De Schamphelaere KAC, Vincze L and Janssen CR. , 2015, Salinity and dissolved organic carbon both affect copper toxicity in mussel larvae: Copper speciation or competition cannot explain everything. Environ Toxicol Chem, 34: 1330-1336 
Dixon DR, Pollard D., 1985, Embryo abnormalities in the periwinkle, Littorina 'saxatilis', as indicators of stress in polluted marine environments. Mar Pollut Bull 16: 29-33

Dziubińska, A, 2011, Mytilopsis leucophaeata, an alien dreissenid bivalve discovered in the Gulf of Gdańsk (southern Baltic Sea). Oceanologia 53:651-655

Fichet D, Miramand P., 1998, Vanadium toxicity to three marine invertebrate larvae: Crassostrea gigas, Paracentrotus lividus and Artemia salina. Chemosphere 37: 1363-1368

Finch BE, Stefansson ES, Langdon CJ, Pargee SM, Blunt SM, Gage SJ, Stubblefield WA., 2016, Photo-enhanced toxicity of two weathered Macondo crude oils to early life stages of the eastern oyster (Crassostrea virginica). Mar Pollut Bull 113: 316-323

Fuller SC, Lutz RA., 1989, Shell morphology of larval and post-larval mytilids from the northwestern Atlantic. J Mar Biol Ass U K 69: 181-218

Gamain P, Gonzalez P, Cachot J, Pardon P, Tapie N, Gourves PY, Budzinski H, Morin B., 2016, Combined effects of pollutants and salinity on embryo-larval development of the Pacific oyster, Crassostrea gigas. Mar Environ Res 113:31-38

Garland ED, Zimmer CA (2002) Techniques for the identification of bivalve larvae. Mar Ecol Prog Ser 225:299-310

HELCOM, 2010, Hazardous substances in the Baltic Sea - An integrated thematic assessment of hazardous substances in the Baltic Sea. Balt Sea Environ Proc No. 120B

Hendriks IE, van Duren LA, Herman PMJ (2005) Image analysis techniques: a tool for the identification of bivalve larvae? J Sea Res 54:151-162

His E, Beiras R, Seaman MNL., 1999, The assessment of marine pollution - Bioassays with bivalve embryos and larvae. Adv Mar Biol 37:1-178

His E, Seaman MNL, Beiras R., 1997, A simplification of the bivalve embryogenesis larval development bioassay method for water quality assessment. Water Res 31:351-355

Hrs-Brenko M, Claus C, Bubić S., 1977, Synergistic effects of lead, salinity and temperature on embryonic development of the mussel Mytilus galloprovincialis. Mar Biol 44:109-115

Inoue S, Oshima Y, Usuki H, Hamaguchi M, Hanamura Y, Kai N, Shimasaki Y, Honjo T., 2006, Effects of tributyltin maternal and/or waterborne exposure on the embryonic development of the Manila clam, Ruditapes philippinarum. Chemosphere 63:881-888

Janas U, Kendzierska H, Dąbrowska A H, Dziubińska A, 2014, Non-indigenous bivalve-the Atlantic rangia Rangia cuneata -in the Wisła Śmiała River (coastal waters of the Gulf of 
Gdańsk, the southern Baltic Sea). Oceanological and Hydrobiological Studies, 43(4): 427430

Józefczuk A, Guzera E, Bielecka L., 2003, Short-term and seasonal variability of mesozooplankton at two coastal stations (Gdynia, Sopot) in the shallow water zone of the Gulf of Gdańsk. Oceanologia 45: 317-336

Klöckner K, Rosenthal H, Willführ J., 1985, Invertebrate bioassays with North Sea water samples. I. Structural effects on embryos and larvae of serpulids, oysters and sea urchins. Helgol Meeresunters 39: 1-19

Korpinen S, Meidinger M, Laamanen M, 2013, Cumulative impacts on seabed habitats: an indicator for assessments of good environmental status. Mar Pollut Bull 74: 311-319

Korpinen S, Meski L, Andersen JH, Laamanen M, 2012, Human pressures and their potential impact on the Baltic Sea ecosystem. Ecol Indic 15: 105-114

Kruk-Dowgiałło L, Szaniawska A., 2008, Gulf of Gdańsk and Puck Bay. Part. II.B Eastern Baltic Coast [in:] Ecology of Baltic Coastal Waters, Ed. U. Schewier, Ecological Studies 197, Springer-Verlag Berlin Heidelberg: 139-162

Kurihara H, Asai T, Kato S, Ishimatsu A., 2008, Effects of elevated pCO2 on early development in the mussel Mytilus galloprovincialis. Aquat Biol 4: 225-233.

Larsen JB, Frischer ME, Rasmussen LJ, Hansen BW., 2005, Single-step nested multiplex PCR to differentiate between various bivalve larvae, Mar Biol 146: 1119-1129.

Larsen JB, Frischer ME, Ockelmann KW, Rasmussen LJ, Hansen BW., 2007, Temporal occurrence of planktotrophic bivalve larvae identified morphologically and by single step nested multiplex PCR. J Plankton Res 29 (5):423-436

Lasota R, Piłczyńska J, Williams ST, Wołowicz M., 2013, Fast and easy method for total DNA extraction and gene amplification from larvae, spat and adult mussels Mytilus trossulus from the Baltic Sea, Oceanol Hydrobiol St 42 (4): 486-489

Le Goff-Vitry MC, Chipman AD, Comtet T., 2007a, In situ hybridization on whole larvae: a novel method for monitoring bivalve larvae. Mar Ecol Prog Ser 343:161-172

Le Goff-Vitry MC, Jacquelin S, Comtet T., 2007b, Towards tracking marine larvae with in situ hybridization. J Mar Biol Ass U K 87:1077-1080

Lehnberg W, Theede H., 1979, Kombinierte Wirkungen von Temperatur, Salzgehalt und Cadmium auf Entwicklung, Wachstum und Mortalität der Larven von Mytilus edulis aus der westlichen Ostsee. Helgol Wiss Meeresunters 32:179-199 
Lehtonen KK, Sundelin B, Lang T, Strand J., 2014, Development of tools for integrated monitoring and assessment of hazardous substances and their biological effects in the Baltic Sea. Ambio 43:69-81

Leinio S, Lehtonen KK., 2005, Seasonal variability in biomarkers in the bivalves Mytilus edulis and Macoma balthica from the northern Baltic Sea, Comp Biochem Phys C 140: 408-421

Liu Y, Guan Y, Yang Z, Cai Z, Mizuno T, Tsuno H, Zhu W, Zhang X., 2009, Toxicity of seven phthalate esters to embryonic development of the abalone Haliotis diversicolor supertexta. Ecotoxicology 18: 293-303

Löf M, Sundelin B, Bandh C, Gorokhova E., 2016, Embryo aberrations in the amphipod Monoporeia affinis as indicators of toxic pollutants in sediments: a field evaluation. Ecol Indic 60: $18-30$

Mai H, Cachot J, Brune J, Geffard O, Belles A, Budzinski H, Morin B., 2012, Embryotoxic and genotoxic effects of heavy metals and pesticides on early life stages of Pacific oyster (Crassostrea gigas). Mar Pollut Bull 64: 2663-2670

Money C, Braungardt CB, Jha AN, Worsfold PJ, Achterberg EP., 2011, Metal speciation and toxicity of Tamar Estuary water to larvae of the Pacific oyster, Crassostrea gigas. Mar Environ Res 72: 3-12

Mudrak S, Żmijewska MI., 2007, Spatio-temporal variability of mesozooplankton from the Gulf of Gdańsk (Baltic Sea) in 1999-2000. Oceanol Hydrobiol St 36: 3-19

Naidenko T., 1997, Abnormality of development in Strongylocentrotus intermedius (A. Agassiz) larvae from polluted habitat in Amursky Bay, Peter the Great Bay. Publ Seto Mar Biol Lab 38:1-11

Newkirk G., 1978, Interaction of genotype and salinity in larvae of the oyster Crassostrea virginica. Mar Biol 48:227-234

Pain-Devin S, Cossu-Leguille C, Geffard A, Giambérini L, Jouenne T, Minguez L, Naudin B, Parant M, Rodius F, Rousselle P, Tarnowska K, Daguin-Thiébaut C, Viard F, Devin S., 2014, Towards a better understanding of biomarker response in field survey: a case study in eight populations of zebra mussels. Aquat Toxicol $155: 52-61$

Parker LM, Ross PM, O'Connor WA., 2010, Comparing the effect of elevated $\mathrm{pCO}_{2}$ and temperature on the fertilization and early development of two species of oysters. Mar Biol 157:2435-2452 
Pineda MC, McQuaid CD, Turon X, López-Legentil S, Ordóñez V, Rius M., 2012, Tough adults, frail babies: an analysis of stress sensitivity across early life-history stages of widely introduced marine invertebrates. PloS ONE 7:e46672

Przeslawski R, M Byrne, Mellin C., 2015, A review and meta-analysis of the effects of multiple abiotic stressors on marine embryos and larvae. Glob Change Biol 21: 2122-2140

Quiniou F, Damiens G, Gnassia-Barelli M, Geffard A, Mouneyrac C, Budzinski H, Roméo M., 2007, Marine water quality assessment using transplanted oyster larvae. Environ Int 33: 2733

Rainbow PS, Phillips DJH., 1993, Cosmopolitan biomonitors of trace metals. Mar Pollut Bull 26:593-601

Renault T, Novoa B., 2004, Viruses infecting bivalve molluscs. Aquat Living Resour 17:397409

Reutgard M, Eriksson Wiklund A-K, Breitholtz M, Sundelin B., 2014, Embryo development of the benthic amphipod Monoporeia affinis as a tool for monitoring and assessment of biological effects of contaminants in the field: a meta-analysis. Ecol Indic 36:483-490

Smolarz K, Bradtke K., 2011, Bioindicative potential of shell abnormalities occurring in the clam Macoma balthica (L.) from the Baltic Sea. Mar Pollut Bull 62:1421-1426

Sokołowski A, Fichet D, Garcia-Meunier P, Radenac G, Wołowicz M, Blanchard G., 2002, The relationship between metal concentrations and phenotypes in the Baltic clam Macoma balthica (L.) from the Gulf of Gdansk, southern Baltic. Chemosphere 47: 475-484

Sokołowski A, Pawlikowski K, Wołowicz M, Garcia P, Namieśnik J., 2008, Shell deformations in the Balthic clam Macoma balthica from southern Baltic Sea (the Gulf of Gdańsk): hypotheses on environmental effects, Ambio 37: 93-100.

Sokołowski A, Wołowicz M, Hummel H, Smolarz-Górska K, Fichet D, Radenac G, ThiriotQuiévreux, Namieśnik J., 2004, Abnormal features of Macoma balthica (Bivalvia) in the Baltic Sea: alerting symptoms of environmental adversity?, Mar Pollut Bull 49: 17-22

Sokołowski A, Ziółkowska M, Balazy P, Kukliński P, Plichta I, 2017, Seasonal and multi-annual patterns of colonisation and growth of sessile benthic fauna on artificial substrates in the brackish low-diversity system of the Baltic Sea. Hydrobiologia 790:183-200

Staniszewska M, Falkowska L, Grabowski P, Kwaśniak J, Mudrak-Cegiołka S, Reindl AR, Sokołowski A, Szumiło E, Zgrundo A, 2014, Bisphenol A, 4-tert-octylphenol, 4-nonylphenol in the Gulf of Gdansk (Southern Baltic) Arch Environ Con Tox 67: 335-347 
Stefansson ES, Langdon CJ, Pargee SM, Blunt SM, Gage SJ, Stubblefield WA., 2016, Acute effects of non-weathered and weathered crude oil and dispersant associated with the Deepwater Horizon incident on the development of marine bivalve and echinoderm larvae. Environ Toxicol Chem 35:2016-2028

Stickney AP., 1964, Salinity, temperature, and food requirements of soft-shell clam larvae in laboratory culture. Ecology 45:283-291

Sundelin B, Eriksson A-K., 1998, Malformations in embryos of the deposit-feeding amphipod Monoporeia affinis in the Baltic Sea. Mar Ecol Prog Ser 171:165-180

Sunila I, Lindström R., 1985, Survival, growth and shell deformities of copper- and cadmiumexposed mussels (Mytilus edulis L.) in brackish water, Estuar Coast Shelf S 21: 555-565

Vaschenko MA, Syasina IG, Zhadan PM, Medvedeva LA, 1997, Reproductive function state of the scallop Mizuhopecten yessoensis Jay from polluted areas of Peter the Great Bay, Sea of Japan. Hydrobiologia 352: 231-240

Vignier J, Donaghy L, Soudant P, Chu F-LE, Morris JM, Carney MW, Layd C, Krasnec M, Robert R, Volety AK, 2015, Impacts of Deepwater Horizon oil and associated dispersant on early development of the Eastern oyster Crassostrea virginica. Mar Pollut Bull 100:426-437 von Westernhagen H, Dethlefsen V, Cameron P, Berg J, Fiirstenberg G., 1988, Developmental defects in pelagic fish embryos from the western Baltic. Helgol Meeresunters 42:13-36

Waldbusser GG, Hales B, Langdon CJ, Haley BA, Schrader P, Brunner EL, Gray MW, Miller CA, Gimenez I, Hutchinson G., 2015, Ocean acidification has multiple modes of action on bivalve larvae. PloS ONE 10:e0128376.

Warzocha J, Szymanek L, Witalis B, Wodzinowski T, 2016, The first report on the establishment and spread of the alien clam Rangia cuneata (Mactridae) in the Polish part of the Vistula Lagoon (southern Baltic). Oceanologia 58:54-58

Wedderburn J, McFadzen I, Sanger RC, Beesley A, Heath C, Hornsby M, Lowe D., 2000, The field application of cellular and physiological biomarkers, in the mussel Mytilus edulis, in conjunction with early life stage bioassays and adult histopathology, Mar Pollut Bull 40: 257267.

Weis JS., 2014, Physiological, developmental and behavioral effects of marine pollution. Springer, Dordrecht, Germany, 452p.

Węsławski JM, Kryla-Straszewska L, Warzocha J, Urbanski J, Włodarska-Kowalczuk M, Kotwicki L., 2013 How lonely they are? A degree of isolation among macrozoobenthos 
species in the Marine Protected Area, the Bay of Puck, the Southern Baltic Oceanol Hydrobiol St 42,289-295

Yap CK, Ismail A, Tan SG, Omar H., 2002, Occurrence of shell deformities in green-lipped mussel Perna viridis (Linnaeus) collected from Malaysian coastal waters, B Environ Contam Tox 69: 877-884. 